\title{
SHANK3 wt Allele
}

National Cancer Institute

\section{Source}

National Cancer Institute. SHANK3 wt Allele. NCI Thesaurus. Code C75397.

Human SHANK3 wild-type allele is located in the vicinity of 22q13.3 and is approximately $59 \mathrm{~kb}$ in length. This allele, which encodes SH3 and multiple ankyrin repeat domains protein 3, may play a role in neuronal function. Mutations in this gene are associated with $22 q$ telomere deletion syndrome. 